\title{
Errata
}

Brachybacterium muris sp. nov., isolated from the liver of a laboratory mouse strain

\author{
S. Buczolits, P. Schumann, G. Weidler, C. Radax and H.-J. Busse
}

International Journal of Systematic and Evolutionary Microbiology (2004), 53, part 6, 1955-1960

In the paper, strain DSM $15460^{\mathrm{T}}$ is erroneously cited as DSM $14560^{\mathrm{T}}$ (T. Kudo, personal communication).

\section{Streptomyces africanus sp. nov., a novel streptomycete with blue aerial mycelium}

P. R. Meyers, C. M. Goodwin, J. A. Bennett, B. L. Aken, C. E. Price and J. M. van Rooyen

International Journal of Systematic and Evolutionary Microbiology (2004), 54, part 5, 1531-1535

The NRRL accession number of Streptomyces africanus (NRRL B-24143 ${ }^{\mathrm{T}}$ ) in the paper is incorrect. According to the NRRL online catalogue, this number is assigned to Corynebacterium aurimucosum (T. Kudo, personal communication). 